DOI: $10.15290 /$ mwtusbwsdb.2019.04

ks. Adam Szot

\title{
PIERWSZY ROK STUDIÓW W BIAŁOSTOCKIM SEMINARIUM DUCHOWNYM
}

Pod koniec II wojny światowej, gdy granice II Rzeczypospolitej zostały już właściwie podzielone i ukształtowane, zgodnie z układem aliantów podpisanym w Jałcie, teren Archidiecezji Wileńskiej został podzielony na trzy obszary: większość Archidiecezji pozostała w granicach dwóch Republik Radzieckich: Litewskiej i Białoruskiej, najmniejsza część znalazła się w granicach Polski Ludowej.

24 marca 1945 roku z Wilna do Białegostoku przyjechali dwaj księża: Jan Krassowski i Aleksander Mościcki, wysłani przez Metropolitę Wileńskiego, abp. Romualda Jałbrzykowskiego, w celu wyszukania odpowiedniej siedziby i zapewnienia środków potrzebnych do właściwego funkcjonowania Seminarium Duchownego i Wydziału Teologicznego. Władze Litewskiej Socjalistycznej Republiki Radzieckiej 20 lutego 1945 roku nakazały zamknąć wileńskie Seminarium Duchowne jako „polski zakład naukowy niedopuszczalny w republice litewskiej”. W związku z obowiązkiem repatriacji i przesiedleń abp Jałbrzykowski, po naradzie z księżmi profesorami, zadecydował o przeniesieniu Seminarium Duchownego i Wydziału Teologicznego Uniwersytetu Stefana Batorego w Wilnie do Białegostoku, czyli w granice Polski.

Jeszcze w Wilnie, jesienią 1944 roku, mianowany z ramienia Polskiego Komitetu Wyzwolenia Narodowego (PKWN), pełnomocnik do przeprowadzenia repatriacji ludności polskiej obiecał abp. Jałbrzykowskiemu, że strona kościelna otrzyma $\mathrm{w}$ Białymstoku odpowiedni gmach nadający się na Seminarium Duchowne w zamian za obiekty, będące własnością kościelną, zabrane w Wilnie. Seminarium było bowiem właścicielem gmachu przy ul. Mostowej 12, ale i dwóch dużych kamienic w centrum miasta, które uległy nacjonalizacji. Przepisy o repatriacji przewidywały odszkodowania dla repatriantów za mienie pozostawione na poprzednich terenach ${ }^{1}$.

Księża wydelegowani z Wilna przez ordynariusza diecezji wspólnie z dziekanem białostockim ks. Aleksandrem Chodyko podjęli starania o właściwy gmach potrzebny Seminarium Duchownemu. Przyszłe władze seminaryjne

Archiwum Państwowe w Białymstoku (dalej: APB), sygn. I-137, k. 10, Pismo Kurii Arcybiskupiej w Białymstoku do Prezydium WRN w Białymstoku, z dn. 5 V 1972 r. 
zabiegały u władz wojewódzkich o odpowiedni obiekt, spełniający wymagania przyszłej uczelni, w zamian za mienie pozostawione w Wilnie. Władze państwowe obiecywały przekazać budynek przy ul. Warszawskiej (naprzeciw wylotu ul. Kościelnej), zajęty jeszcze wówczas przez Armię Czerwonąą ${ }^{2}$ Okazało się jednak, iż strona kościelna od władz miasta nie otrzyma żadnego obiektu spełniającego oczekiwania studentów i profesorów Seminarium.

Trudno było o odpowiedni budynek w centrum, tym bardziej, że w czasie wojny miasto zostało poważnie zniszczone, centrum w około $75 \%$. Najpierw brano więc pod uwagę lokal przy parafii pw. św. Rocha, ale nie spełniał on odpowiednich warunków ${ }^{3}$. Następnie gmachy pozakonne poza Białymstokiem: w Supraślu, a nawet w Różanymstoku. Ostatecznie księża zainteresowali się Zakładem Rzemieślniczo-Wychowawczym pw. św. Józefa przy ul. Słonimskiej 8 , ale po wojnie był on w złym stanie technicznym. Tymczasowo zajmował go jeszcze oddział Armii Czerwonej, ale jego dowódca zgodził się ustąpić z zajmowanego lokalu.

29 marca 1945 roku podpisano umowę dzierżawy lokalu, na 15 lat, przy ul. Słonimskiej $8 \mathrm{w}$ Białymstoku między Jerzym Kockim, przedstawicielem Stowarzyszenia Zakładów Rzemieślniczo-Wychowawczych pw. św. Józefa i prawnym współwłaścicielem i administratorem budynków a ks. Janem Krassowskim, prokuratorem Seminarium Duchownego, działającym z mocy generalnej plenipotencji Kurii Metropolitalnej Wileńskiej. Ksiądz Krassowski działał w imieniu i na rzecz repatriowanego z terytorium Litewskiej Socjalistycznej Republiki Radzieckiej do Polski Seminarium Duchownego ${ }^{4}$.

Wojskowy komendant miasta, zgodnie ze złożoną obietnicą, na początku kwietnia 1945 roku usunął ze Słonimskiej 8 radzieckich żołnierzy, którzy tam dotychczas kwaterowali. Po opuszczeniu obiektu przez wojskowych, 12 tercjarek z III Zakonu św. Franciszka przy parafii farnej zaczęło sprzątanie i oczyszczanie gmachu.

Obiekt przedstawiał stan opłakany. Wymagał ogromnego nakładu sił i środków, aby go przywrócić do stanu używalności i adaptować na potrzeby przyszłego Seminarium Duchownego. Brat Jerzy Kocki i ks. Jan Krassowski, przejmujący obiekt, zgodnie stwierdzili, że najmowane pomieszczenia mieszkalne, wskutek działań wojennych, były w stanie ciężkiego uszkodzenia, niezdatnego do użytkowania bez uprzedniego dokonania w nim kapitalnego

Archiwum Archidiecezjalne w Białymstoku (dalej: AAB), Sprawy lokalowe AWSD Orzeszkowa 5 i Słonimska 8, Pismo biskupa W. Suszyńskiego rektora AWSD do Kuratorium Okręgu Szkolnego Białostockiego, z dn. 4 IV 1960 r.

3 AAB, Kronika Archidiecezjalnego Seminarium Duchownego pod wezwaniem św. Jerzego Męcz. w Białymstoku, t. I, Białystok 1959, rkps, s. 2.

4 J. Pankiewicz, Dzieje, w: Archidiecezjalne Wyższe Seminarium Duchowne w Białymstoku 19451980, red. E. Ozorowski, Białystok 1981, s. 13-15. 
remontu i przebudowy niektórych lokali stosownie do potrzeb Seminarium Duchownego jako instytucji naukowej, wymagającej urządzenia sal wykładowych, kuchni, jadalni, pomieszczenia na ulokowanie biblioteki i inne.

Przystąpiono do generalnego remontu obiektu. Przedstawiciele Seminarium wyrazili ze swej strony gotowość i zgodę na całkowite poniesienie kosztów, związanych z kapitalnym remontem i przebudową niektórych lokali, oraz zobowiązali się na własny rachunek przeprowadzić remont do stanu zdatnego do użytkowania.

Obie strony podpisując umowę dzierżawy wyraźnie stwierdzały, że brakowało w nim szyb we wszystkich oknach i ram okiennych w niektórych pomieszczeniach. W większości przypadków brak było drzwi do pojedynczych pokoi; brak zamków, klamek, zawiasów zarówno do drzwi, jak i okien. Centralne ogrzewanie i urządzenie kanalizacji wymagały gruntownego remontu i naprawy. Grzejniki centralnego ogrzewania wymagały w przeważającej części zmiany, częściowo przeczyszczenia i zmiany rur łącznikowo-przewodowych, a to wskutek uszkodzeń, powstałych podczas eksplozji miny, założonej w celach niszczycielskich przez hitlerowców. W toaletach zachodziła pilna konieczność ustawienia mis i sedesów klozetowych. Najmowane pomieszczenie wymagało naprawy i przeprowadzenia nowej instalacji elektrycznej w poszczególnych salach ${ }^{5}$.

Z chwilą objęcia pomieszczeń w użytkowanie faktycznym najemcą stała się Kuria Metropolitalna Wileńska oraz działający z jej ramienia Zarząd Seminarium Duchownego w Białymstoku, w osobach rektora i prokuratora tegoż Seminarium.

Przedstawiciel Stowarzyszenia Zakładów Rzemieślniczo-Wychowawczych pw. św. Józefa, licząc się z poważnym nakładem prac i środków pieniężnych zainwestowanych przez Seminarium Duchowne w doprowadzeniu pomieszczeń mieszkalnych do stanu zdatnego do użytkowania, oddawał bezpłatnie w użytkowanie stronie seminaryjnej obiekt przy ul. Słonimskiej 8 do dnia 31 grudnia 1960 roku. Wszelkie adaptacje i remonty pomieszczeń miał przeprowadzać najemca na swój koszt.

Gmach przy ul. Słonimskiej 8 został wynajęty Seminarium Duchownemu na okres 15 lat. Władze seminaryjne zobowiązywały się, że gmach nie będzie użytkowany do innego celu, aniżeli to podano w umowie najmu. Nie można było, bez pisemnego zezwolenia wynajmującego, przenosić praw z tej umowy wypływających na osoby trzecie w całości lub części. Najemca został 
też zobowiązany do należytej troski o gmach, miał go utrzymywać w stanie zgodnym z ówczesnymi przepisami sanitarno-policyjnymi ${ }^{6}$.

Dzięki podpisanej ze Zgromadzeniem zakonnym umowie, Seminarium Duchowne otrzymało większą część budynku, w sumie 16 pokoi, kaplicę i kuchnię, która była nową inwestycją, zbudowaną specjalnie na potrzeby przyszłego Seminarium. Do porządku doprowadzono korytarze i klatkę schodową. Kaplica pełniła funkcję publicznej, gdyż na nabożeństwa przychodziły też osoby z zewnątrz. Pozostałą część gmachu zajmowali „braciszkowie". W ich części mieściła się piekarnia oraz sklep.

Po dokonaniu koniecznych remontów i porządków, zakupieniu niezbędnych sprzętów lub pożyczeniu ich od duchowieństwa, a nawet mieszkańców miasta, od końca kwietnia 1945 roku gmach był gotowy na przyjęcie kleryków i profesorów. 27 kwietnia 1945 roku zakończono prace porządkowe i przeniesiono do gmachu niezbędny sprzęt i pomoce naukowe. Uruchomiono wówczas kaplicę, poświęconą w 1933 roku, z ołtarzem Świętej Rodziny w środkowej nawie, a w niedzielę 6 maja 1945 roku została ponownie poświęcona przez ks. Aleksandra Mościckiego 7 .

30 kwietnia 1945 roku do Białegostoku, jako tzw. repatrianci, przyjechali księża profesorowie Uniwersytetu Stefana Batorego, z rektorem na czele. Byli to: ks. Ignacy Świrski, ks. Czesław Falkowski, ks. Paweł Nowicki, ks. Antoni Pawłowski, ks. Michał Klepacz, ks. Władysław Suszyński i ks. Walenty Urmanowicz.

Już we wrześniu 1944 roku, tuż po odzyskaniu wolności i po powrocie z miejsca internowania w Mariampolu do Wilna, abp R. Jałbrzykowski skierował pismo adresowane do duchowieństwa Archidiecezji w sprawie Seminarium Duchownego, które w październiku 1944 roku miało zostać otwarte w Wilnie. Ordynariusz wiedział, że przyszłość Seminarium nierozdzielnie związana będzie z ofiarnością duchowieństwa i wiernych. W pierwsze dwie niedziele listopada 1944 roku we wszystkich kościołach zebrane zostały ofiary na tacę i za pośrednictwem dziekanów przekazane na rzecz Seminarium ${ }^{8}$.

Pracownicy uniwersyteccy, niezwiązani z Wydziałem Teologicznym USB i Seminarium Duchownym, pojechali do Torunia i dali tam początek Uniwersytetowi Mikołaja Kopernika; księża pozostali w Białymstoku. Tego dnia odbyła się pierwsza sesja księży profesorów Wydziału Teologicznego USB i Seminarium Duchownego w Białymstoku.

\footnotetext{
6 Umowa wynajmu budynku przy ul. Słonimskiej $8 \mathrm{w}$ Białymstoku, w: A. Szot, Słonimska 8. Dom pachnacy chlebem Dzieje Zgromadzenia Braci Stug Maryi Niepokalanej, s. 197-201.

7 M. Paszkiewicz, Kronika Seminarium Duchownego w Białymstoku 1945-1966, Białystok, mps, s. 3.

8 AAB, Pismo ks. A. Chodyki, dziekana białostockiego, do ks. prob. z Uhowa, z 10 X 1944 r.
} 
Na pierwszej sesji w dniu 30 kwietnia 1945 roku, protokołowanej, uczestniczyło ośmiu duchownych, księży profesorów Wileńskiego Rzymsko-Katolickiego Duchownego Seminarium w Białymstoku. Byli to: ks. Aleksander Chodyko - proboszcz i dziekan białostocki, ks. Ignacy Świrski - rektor, ks. prof. Czesław Falkowski - rektor, ks. prof. Michał Klepacz - dziekan Wydziału Teologicznego USB, ks. prof. Paweł Nowicki, ks. prof. Walenty Urmanowicz, ks. Aleksander Mościcki - inspektor, ks. Jan Krassowski - prokurator ${ }^{9}$.

Znamienne jest to, że to ks. Chodyko, jako gospodarz parafii w Białymstoku rozpoczął obrady, przywitał księży profesorów, którzy przybyli z Wilna do Białegostoku, a następnie rektorowi Seminarium ks. I. Świrskiemu przekazał głos i przewodniczenie. Proboszcz parafii farnej zakomunikował zebranym, że otrzymał od abp. Romualda Jałbrzykowskiego pełnomocnictwo, jako wikariusz generalny, i polecenie otwarcia w Białymstoku Seminarium Duchownego. Przedstawił przebieg okoliczności i wykaz podjętych kroków w celu zorganizowania w gmachu przy ul. Słonimskiej 8 wyższej uczelni. Podobne sprawozdanie złożył ks. Aleksander Mościcki, który wraz z ks. Janem Krassowskim zostali przez Metropolitę Wileńskiego wydelegowani z Wilna, aby w Białymstoku zorganizować Seminarium Duchowne.

Po wysłuchaniu obu tych relacji, dziekan ks. Chodyko stwierdził, iż istotna część zadania dla uruchomienia w Białymstoku Seminarium Duchownego została już wykonana i wniósł prośbę o wyznaczenie terminu otwarcia Seminarium na 8 maja 1945 roku. Propozycję tę księża profesorowie przyjęli jednomyślnie. Rektor ks. Ignacy Świrski zaproponował obsadzenie stanowiska ojca duchownego w białostockim Seminarium Duchownym ks. Stanisławowi Sielukowi, dotychczasowemu wikariuszowi parafii pw. św. Rocha w Białymstoku ${ }^{10}$.

Dzień później księża profesorowie spotkali się ponownie. Dyskutowali nad terminem rozpoczęcia zajęć seminaryjnych i inauguracją roku akademickiego. Zapoznali się ze sprawozdaniem kasowym, czyli z kosztami remontu i adaptacji nowego gmachu Seminarium. Poruszono kwestię zaproszenia do grona wykładowców seminaryjnych nowych księży profesorów, jak również sprawę powrotu do Seminarium alumnów przebywających w innych polskich seminariach duchownych ${ }^{11}$.

Seminarium Duchowne, przeniesione z Wilna do Białegostoku, postanowiono otworzyć 8 maja 1945 roku, w uroczystość św. Stanisława, Biskupa i Męczennika, głównego patrona Polski. Inaugurację roku akademickiego

9 AAB, Księga protokołów sesji księży profesorów Seminarium Duchownego, z lat 1944-1948, protokół z dn. 30 IV $1945 \mathrm{r}$.

10 Ibidem.

11 AAB, Księga protokołów sesji księży profesorów Seminarium Duchownego, z lat 1944-1948, protokół z dn. 31 IV [błąd w zapisie, chodziło najprawdopodobniej o 1 V] 1945 r. 
zaplanowano na 24 maja. Jej przebieg miał wyglądać następująco: o godz. 10.00 Mszę św. miał odprawić ks. A. Mościcki; po Mszy św. w sali rekreacyjnej mieli się zebrać zaproszeni goście, księża profesorowie i alumni; jako pierwszy miał do nich przemówić proboszcz parafii pw. Wniebowzięcia Najświętszej Maryi Panny w Białymstoku ks. A. Chodyko, wikariusz generalny; następnie głos miał zabrać przedstawiciel Seminarium - rektor, ks. I. Świrski. Zaplanowano również zwiedzanie nowej siedziby Seminarium, by wszyscy zaproszeni księża mogli zobaczyć gmach wynajęty na potrzeby duchownej uczelni ${ }^{12}$. Nie wiemy dokładnie, czy inauguracja roku akademickiego miała zaplanowany przebieg, dlatego pozostawiam tu pewne niedopowiedzenia.

Plan został zrealizowany, choć uległ pewnym zmianom. Mszy św. w kaplicy seminaryjnej, w uroczystość św. Stanisława, Biskupa i Męczennika, przewodniczył ks. Stanisław Sieluk, solenizant. Został on mianowany jeszcze w Wilnie przez abp. Jałbrzykowskiego ojcem duchownym białostockiego Seminarium. On też pierwszy przemówił do zebranych dając wyraz radości, że Seminarium w Białymstoku rozpoczęło swą działalność w dniu głównego Patrona Polski.

Rektor Seminarium i dziekan Wydziału Teologicznego USB w Wilnie ks. prof. I. Świrski w swym słowie zobrazował przedwojenne osiągnięcia Wydziału Teologicznego, ale podzielił się też trudnościami, jakie zaistniały wskutek zmian politycznych po II wojnie światowej w Wilnie. Ale wyraził też nadzieję, że praca Wydziału w Białymstoku będzie nie mniej chlubna niż w Wilnie.

Dopiero po rektorze przemówił ks. Aleksander Chodyko, jako gospodarz białostockiej parafii. Tego dnia, 8 maja 1945 roku, przeżywał jubileusz 40-lecia swej Mszy św. prymicyjnej. Wyraził radość z tego, że udało się po latach wojny zgromadzić na nowo alumnów i profesorów wileńskiego Seminarium Duchownego w jednym miejscu i rozpocząć rok akademicki. Miał nadzieję, że miejscowe duchowieństwo i wiernych stać będzie na utrzymanie duchownej uczelni, a rozpoczęty rok akademicki przyczyni się do zaspokojenia potrzeb duszpasterskich lokalnego Kościoła ${ }^{13}$. Odczyt inauguracyjny na rozpoczęcie zajęć w Seminarium Duchownym wygłosił dziekan Wydziału Teologicznego USB ks. prof. M. Klepacz.

Sprawozdanie kasowe złożył prokurator Seminarium ks. J. Krassowski, natomiast sprawozdanie $\mathrm{z}$ wydatków na remont lokalu przedstawił ks. A. Chodyko. Powołano Komisję Rewizyjną, która miała zajmować się kwestiami finansowymi. W jej skład, na wniosek dziekana ks. Chodyki, weszli księża:

12 AAB, Zaproszenie na inaugurację roku akademickiego w Seminarium Duchownym w Białymstoku, z 21 V 1945 r.

13 M. Paszkiewicz, Kronika Seminarium Duchownego w Białymstoku 1945-1966, Białystok, mps, s. 5-8. 
Franciszek Ratyński - proboszcz parafii w Dobrzyniewie Kościelnym i Franciszek Pieściuk - proboszcz parafii w Choroszczy.

$\mathrm{Na}$ wniosek rektora Seminarium do grona profesorskiego został przyjęty ks. dr Witold Pietkun. Postanowiono, aby alumni wileńskiego Seminarium Duchownego, przebywający wówczas w innych seminariach pozostali w nich do zakończenia roku akademickiego. Po złożeniu egzaminów mieli przybyć do Białegostoku, by kontynuować rozpoczęte studia.

W maju 1945 roku przyjechały z Wilna do Białegostoku również siostry zakonne ze Zgromadzenia Służek Najświętszej Maryi Panny Niepokalanej, które pracowały w kuchni w Seminarium wileńskim od 1922 roku, aby w Białymstoku kontynuować tę posługę.

Proboszcz parafii farnej ks. A. Chodyko, w piśmie skierowanym do duchowieństwa dekanatu białostockiego, z początku maja 1945 roku, stwierdzał, iż spełniając życzenie i wolę abp. Jałbrzykowskiego, doświadczywszy już wielkiej życzliwości z różnych środowisk i ufając w pomoc materialną księży z dekanatów białostockiego i sokólskiego, podjął decyzję o rozpoczęciu zajęć w Seminarium Duchownym w Białymstoku przy ul. Słonimskiej dnia 8 maja 1945 roku. Wszelkie dotychczasowe wydatki pokrył z własnej kieszeni, przy ofiarności mieszkańców miasta i dzięki życzliwości księży z okolicznych parafii. Prosił jednak, by składka na rzecz Seminarium objęła wszystkich księży. Mieli oni do końca kwietnia 1945 roku przesłać jej pierwszą część, ale uczyniło to tylko $10 \%$ księży. Oczekiwał na wpłaty ustalonej składki i na zbiórkę płodów rolnych na rzecz Seminarium. Prosił, by księża udostępnili lub chociaż wypożyczyli na pewien czas, podstawowe elementy wyposażenia domu, jak: łóżko, pościel, stolik, miednicę, wiadro, talerze, zastawy stołowe, sztućce, co niewątpliwie świadczy o powojennej biedzie i bardzo trudnych warunkach materialnych, w jakich rozpoczynało swą działalność Seminarium Duchowne w Białymstoku.

Odpowiedzialność za przygotowanie gmachu na potrzeby Seminarium ponosili nie tylko wyznaczeni przez ordynariusza duchowni, ale także wszyscy księża pozostający na terenie Archidiecezji Wileńskiej w nowo wyznaczonych granicach Polski. Także bracia ze Słonimskiej przyszli z pomocą materialną ofiarowując na remont lokalu kwotę $12100 \mathrm{zł}$ oraz kafle na zbudowanie seminaryjnej kuchni ${ }^{14}$.

Na prośbę ordynariusza diecezji z października 1944 roku i dziekana białostockiego, ks. A. Chodyki z maja 1945 roku, proboszczowie i wikariusze wspierali dobrowolnymi ofiarami przenosiny Seminarium Duchownego z Wilna do Białegostoku. Zachowały się kwity kasowe potwierdzające wpłaty

14 AAB, Księga protokołów sesji księży profesorów Seminarium Duchownego, z lat 1944-1948, protokół z dn. 31 IV [błąd w zapisie, chodziło najprawdopodobniej o 1 V] $1945 \mathrm{r}$. 
poszczególnych kapłanów, na przykład ks. E. Kisiel, późniejszy pierwszy Arcybiskup Białostocki, 11 maja 1945 roku przekazał na potrzeby Seminarium w Białymstoku $2000 \mathrm{z}^{15}$. Z parafii płynęły też dary materialne, zazwyczaj w postaci płodów rolnych, czy najpotrzebniejszych materiałów budowlanych, na przykład drzewa na budulec.

Po dokonaniu koniecznych remontów i porządków, zakupieniu niezbędnych sprzętów lub pożyczeniu ich od duchowieństwa, a nawet mieszkańców miasta, od końca kwietnia 1945 roku gmach był gotowy na przyjęcie kleryków i profesorów. Pierwszy rok zajęć, uzupełniający, miał się rozpocząć 8 maja 1945 roku i trwać przez cztery miesiące, do końca sierpnia 1945 roku $^{16}$.

8 maja 1945 roku 45 kleryków, którzy wrócili z Wilna lub z wojennej tułaczki, uroczyście zainaugurowało pierwszy rok nauki w Wyższym Seminarium Duchownym w Białymstoku ${ }^{17}$. Pierwsi klerycy wyjechali z Wilna już 3 marca 1945 roku w piątym transporcie repatriacyjnym, tzw. nauczycielskim. Większość z nich zatrzymała się w Białymstoku. W marcu i kwietniu 1945 roku przybyło bezpośrednio z Wilna około 20 alumnów $^{18}$. Zgłaszali się do proboszcza parafii pw. Wniebowzięcia Najświętszej Maryi Panny ks. Aleksandra Chodyki, który początkowo udzielał im schronienia na swej plebanii, a następnie rozsyłał do poszczególnych parafii w dekanacie białostockim aż do czasu reaktywowania wileńskiego Seminarium Duchownego w Białymstoku.

Nie wszyscy klerycy przyjechali wiosną 1945 roku z Wilna do Polski. 1 stycznia 1945 roku w wileńskim Seminarium kształciło się 63 alumnów diecezjalnych i 10 zakonników z różnych zgromadzeń zakonnych (marianie, pijarzy, salezjanie, misjonarze św. Wincentego a Paulo) ${ }^{19}$. Dekretem Rady Komisarzy Ludowych Litewskiej Socjalistycznej Republiki Radzieckiej z 15 lutego 1945 roku Wyższe Seminarium Duchowne w Wilnie zamknięto. Powołano do życia jedno Seminarium dla całej Litwy - w Kownie. Klerycy narodowości litewskiej mogli pozostać w LSRR i kontynuować studia w Seminarium Duchownym w Kownie, zaś alumni narodowości polskiej musieli opuścić Wilno. Arcybiskup Romuald Jałbrzykowski, Metropolita Wileński, po naradach z kapitułą i profesorami Wydziału Teologicznego USB, podjął

$15 \quad$ AAB, Kwit kasowy z 11 V 1945 r.

16 AAB, Pismo ks. A. Chodyki, dziekana białostockiego, do ks. prob. z Uhowa, z 4 V 1945 r.

17 AAB, W. Suszyński, op. cit., s. 3.

18 M. Paszkiewicz, Kronika Seminarium Duchownego w Białymstoku 1945-1966, Białystok, mps, S. 2.

19 AAB, Seminarium Duchowne w Wilnie w czasie II wojny światowej, mps; T. Krahel, Przez więzienia i obozy do kapłaństwa. Wojenne losy alumnów Seminarium Duchownego w Wilnie, Białystok 2015, s. 177-178. 
decyzję o przeniesieniu Seminarium do Białegostoku ${ }^{20}$. Była to decyzja konieczna, gdyż w Wilnie konfiskacie uległo już całe mienie seminaryjne wraz z budynkiem. Dnia 20 lutego 1945 roku rektor wileńskiego Seminarium, po przeprowadzonej przez urzędników państwowych niezapowiedzianej rewizji, otrzymał nakaz zaprzestania działalności i opuszczenia zajmowanych budynków ${ }^{21}$. Władze litewskie uważały bowiem, że Seminarium w Wilnie istniało od 1944 roku bez żadnych podstaw prawnych i nakazały ewakuację. Władze seminaryjne, wykładowcy i klerycy otrzymali karty ewakuacyjne. Część alumnów została na Litwie, gdyż władze państwowe wyraźnie nakazały, by Litwini udali się do Seminarium Duchownego w Kownie ${ }^{22}$, a Polacy mieli wyjechać do Polski. Niektórzy porzucili drogę powołania kapłańskiego.

Tabela 1. Wykaz alumnów Seminarium Duchownego w Białymstoku (stan na grudzień $1945^{23}$ )

Kurs I:

1. Bawolski Edward

2. Bogdański Telesfor

3. Błażejewicz Eugeniusz

4. Breczko Antoni

5. Grodzki Bronisław

6. Gulbinowicz Henryk

7. Hlebowicz Czesław

8. Krzywosz Aleksander

9. Lewicki Zygmunt

10. Markiewicz Aleksander

11. Oniszczuk Stanisław

12. Pankiewicz Jan

13. Radulski Aleksander

14. Sielicki Jan

15. Szczepański Stanisław

16. Tarasiuk Stefan

17. Wieromiej Wojciech

\section{Kurs III:}

26. Borys Edward

27. Chilmon Wacław

28. Flejszer Augustyn

29. Hreczanik Stanisław

30. Karaczewski Jan

31. Katinas Piotr

32. Mikłosz Kazimierz

33. Rutkowski Maurycy

34. Wilczewski Franciszek

\section{Kurs IV:}

35. Jasiński Stanisław

36. Rokicki Jarosław

Kurs V:

37. Chmielewski Jan

38. Piotrowski Leon

39. Stopczyński Mieczysław

$20 \quad \mathrm{AAB}, \mathrm{W}$. Suszyński, Informacje o losach Wileńskiego Seminarium Duchownego w czasie wojny od roku 1939 do dnia 5 sierpnia 1946, mps, s. 3.

21 Lietuvas Centrinis Valstybes Archyvas (dalej: LCVA), Litewskie Centralne Archiwum Historyczne w Wilnie, F R-181, op. 1, dz. 6, s. 25.

22 K. Kułak, Wydział Teologiczny Uniwersytetu Stefana Batorego i Metropolitalne Seminarium Duchowne w Wilnie w czasie II wojny światowej, Lublin 1986, mps w BKUL, s. 101-102.

23 AAB, Księga egzaminów; T. Krahel, Przez więzienia i obozy do kapłaństwa. Wojenne losy alumnów Seminarium Duchownego w Wilnie, s. 179; J. Pankiewicz, Dzieje, w: Archidiecezjalne Wyższe Seminarium Duchowne w Białymstoku 1945-1980, red. E. Ozorowski, s. 22-24. 


\begin{tabular}{|l|l|}
\hline Kurs II: & \multicolumn{2}{|l|}{ Kurs VI: } \\
18. Cierpik Marian & 40. Bielaj Eugeniusz \\
19. Gabrycki Zygfryd & 41. Brzozowski Henryk \\
20. Kułak Kazimierz & 42. Kruk Antoni \\
21. Kuźmicki Mieczysław & 43. Laszuk Władysław \\
22. Łogutko Czesław & 44. Niemotko Józef \\
23. Mikołajewicz Alfred & 45. Wieczorkowski Zbigniew \\
24. Pietkiewicz Edward & \\
25. Radziewicz Stanisław & \\
\hline
\end{tabular}

17 marca 1945 roku w bazylice katedralnej pw. św. Stanisława w Wilnie abp. Jałbrzykowski udzielił święceń kapłańskich pięciu diakonom i święceń diakońskich dwóm kandydatom do kapłaństwa ${ }^{24}$. Ostatnich święceń kapłańskich przed wyjazdem do Polski udzielił 3 czerwca 1945 roku diakonowi o. Stanisławowi Pietraszowi, pijarowi ${ }^{25}$.

Pierwszym rektorem Archidiecezjalnego Wyższego Seminarium Duchownego w Białymstoku został ks. Ignacy Świrski, profesor Uniwersytetu Stefana Batorego w Wilnie. Nominacja na rektora białostockiej uczelni wystawiona została przez abp. Jałbrzykowskiego 14 maja 1945 roku.

Ignacy Świrski urodził się 20 września 1885 roku w rodzinie ziemiańskiej, w miejscowości Ellerne, w Inflantach Polskich, k. Dyneburga ${ }^{26}$. Był czwartym z sześciorga dzieci Michała i Emilii z d. Saulewicz. Nauki pobierał w domu rodzinnym, a następnie w Dyneburgu. Egzamin dojrzałości zdał w Gimnazjum Aleksandra I w Petersburgu. Po maturze w 1904 roku wstąpił do Seminarium Duchownego Archidiecezji Mohylewskiej w Petersburgu, gdzie wykazał się nieprzeciętnymi zdolnościami intelektualnymi. Jeszcze jako alumn w 1907 roku został wysłany z Petersburga do Rzymu, na dalsze studia na Papieskim Uniwersytecie Gregoriańskim. W Wiecznym Mieście zamieszkał w Collegium Germanicum pod nazwiskiem Schwarz, ponieważ w tamtych czasach Polacy nie mogli formalnie studiować na Gregorianum. Oprócz studium z zakresu filozofii i teologii uczył się także greki i łaciny oraz poznawał współczesne języki nowożytne (francuski, niemiecki, włoski). W 1910 roku uzyskał doktorat z filozofii, a w 1914 roku doktorat z teologii. 28 października 1913 roku w Rzymie, z rąk kard. Basilio Pompili, ówczesnego wikariusza generalnego diecezji rzymskiej, otrzymał święcenia kapłańskie. Pierwszą Mszę św. odprawił w kościele Il Gesù przy grobie swojego patrona św. Ignacego Loyoli.

24 Biblioteka Litewskiej Akademii Nauk w Wilnie (dalej: BLAN), F 31-19375, Lista święconych 17 marca 1945 r.; T. Krahel, Przez więzienia i obozy do kapłaństwa. Wojenne losy alumnów Seminarium Duchownego w Wilnie, s. 45.

25 Pamięci ks. Adolfa Trusewicza, „Magazyn Wileński” 2001, nr 5, s. 37.

26 J. Pankiewicz, Ignacy Świrski 1945-1946, w: Archidiecezjalne Wyższe Seminarium Duchowne w Białymstoku 1945-1980, red. E. Ozorowski, s. 129-133. 
Po powrocie do Petersburga w 1914 roku został profesorem i ojcem duchownym w Seminarium Duchownym. Od stycznia 1918 roku był kierownikiem Katedry teologii moralnej w Akademii Duchownej w Petersburgu. W czerwcu 1918 roku bolszewicy zamknęli Akademię Duchowną. Ksiądz Świrski udał się do Dyneburga, gdzie od września 1918 do marca 1919 roku pracował jako nauczyciel i dyrektor gimnazjum polskiego ${ }^{27}$.

Po odzyskaniu przez Polskę niepodległości zgłosił się na ochotnika do Wojska Polskiego. Został kapelanem szpitala polowego i proboszczem garnizonu mińskiego, a następnie proboszczem 9 dywizji i dziekanem IV Armii Wojska Polskiego, dowodzonej przez gen. Leonarda Skierskiego. Służbę w Wojsku Polskim ukończył 1 września 1921 roku w stopniu podpułkownika.

Po wskrzeszeniu w Wilnie Uniwersytetu 18 września 1921 roku został kierownikiem Katedry teologii moralnej na Wydziale Teologicznym Uniwersytetu Stefana Batorego w Wilnie. Do wybuchu II wojny światowej był kilkakrotnie dziekanem Wydziału Teologicznego, na którym wykładał teologię moralną (1921-1939), filozofię (1928-1939) i teologię pastoralną (19271928). Udzielał się w pracach Towarzystwa Przyjaciół Nauk oraz Polskiego Towarzystwa Teologicznego, a także prowadził duszpasterstwo akademickie; przez szereg lat był kuratorem bursy akademickiej.

Po zamknięciu przez radzieckie, a następnie litewskie władze okupacyjne Uniwersytetu we wrześniu 1939 roku wciąż pracował w Seminarium Duchownym w Wilnie, gdzie wykładał teologię moralną i psychologię. Uniknął aresztowania w dniu 3 marca 1942 roku. Do końca sierpnia 1944 roku ukrywał się poza Wilnem, w majątku Zacharyszki, k. Turgiel. Po wznowieniu 1 października 1944 roku zajęć seminaryjnych prowadził wykłady w Wilnie. 20 lutego 1945 roku władze litewskie zamknęly Seminarium. Metropolita Wileński przeniósł uczelnię do Białegostoku, dokąd specjalnym transportem uniwersyteckim ks. Świrski przybył wraz z zasadniczą grupą księży profesorów 30 kwietnia 1945 roku. 8 maja 1945 roku rozpoczął wykłady w Białymstoku ${ }^{28}$.

Jego najbliższymi współpracownikami byli księża mający nieraz długoletnie doświadczenie akademickie, ale także duchowni, którzy dopiero rozpoczynali pracę z alumnami. Wicerektorem w białostockim Seminarium był ks.

27 J. Zawadzki, Biskup Ignacy Świrski (1885-1968), „Callectanae Theologica” 38(1968), f. IV, s. 155-157; J. Skorodiuk, Historia życia biskupa I. Świrskiego, „Chrześcijanie”, t. 17, red. B. Bejze, Warszawa 1986, s. 13-22; J. Skorodiuk, Cechy osobowe biskupa Ignacego Świrskiego, „Studia Włocławskie” 12(2009), s. 92-105. Z. Młynarski, Śp. Ksiądz Biskup Ignacy Świrski, „Gość Niedzielny" 38(1969), nr 17, s. 100.

28 T. Krahel, Przez więzienia i obozy do kapłaństwa. Wojenne losy alumnów Seminarium Duchownego w Wilnie, Białystok 2015, s. 63; A. Skreczko, Ks. Ignacy Świrski-wychowawca i profesor (okres wileński i białostocki), w: Biskup Ignacy Świrski 1885-1968. Osoba i dzieło, red. B. Błoński, Siedlce 2008. 
Aleksander Mościcki, ojcem duchownym ks. Stanisław Sieluk, a ekonomem (prokuratorem) ks. Jan Krassowski. Wykładowcami zostali profesorowie Wydziału Teologicznego USB, reaktywowanego przez abp. Jałbrzykowskiego $\mathrm{w}$ Białymstoku ${ }^{29}$ i profesorowie Seminarium ${ }^{30}$. Z upływem tygodni i miesięcy wzrastało grono profesorów i wykładowców, rosła też liczba alumnów. Do Białegostoku docierali kolejni profesorowie, między innymi ks. Władysław Rusznicki i ks. Władysław Suszyński. Wracali klerycy wywiezieni do Niemiec, zgłaszali się także nowi kandydaci.

Dnia 15 lipca 1945 roku z Wilna do Białegostoku przybył abp Romuald Jałbrzykowski. Został zmuszony do opuszczenia swej stolicy biskupiej przez komunistyczne władze Litwy. Od tej chwili osobiście zainteresował się sprawami Seminarium Duchownego i Wydziału Teologicznego, między innymi podjął wykłady $\mathrm{z}$ teologii pastoralnej.

Pod koniec 1945 roku w skład Zarządu Seminarium wchodzili następujący księża: ks. dr Ignacy Świrski - rektor Seminarium, wykładowca teologii moralnej i psychologii; ks. dr Władysław Suszyński - inspektor, wykładowca prawa kanonicznego, kosmologii i historii filozofii; ks. dr Aleksander Mościcki - prefekt, wykładowca katolickiej nauki społecznej, pedagogiki i prawa wyznaniowego i ks. Stanisław Sieluk - ojciec duchowny, wykładowca liturgiki, teologii ascetycznej i teologii orientalnej. Grono profesorów - wykładowców uzupełniali księża: abp dr Romuald Jałbrzykowski, dr Czesław Falkowski, dr Michał Klepacz, dr Paweł Nowicki, dr Walenty Urmanowicz, lic. mgr Władysław Rusznicki. Przez pewien okres zajęcia w Seminarium prowadzili również księża: dr Antoni Pawłowski i dr Witold Pietkun. Do pierwszej sesji egzaminacyjnej w grudniu 1945 roku w białostockim Seminarium przystąpiło 45 kleryków ${ }^{31}$.

3 lutego 1946 roku w białostockiej prokatedrze, z rąk abp. Jałbrzykowskiego, święcenia kapłańskie otrzymali diakoni: Eugeniusz Bielaj, Henryk Brzozowski, Józef Kruk, Władysław Łaszczuk, Zbigniew Wieczorkowski. Uroczystość poprzedziły trzydniowe rekolekcje przed święceniami wyższymi i niższymi, które przeprowadził ks. Sieluk ${ }^{32}$.

Dzięki doświadczeniu, jakie zdobył abp Jałbrzykowski będąc wiceregensem w Sejnach i rektorem Seminarium w Łomży, dobrze orientował się we wszystkich dziedzinach życia tej uczelni. W miarę swych możliwości hospitował

29 AAB, Sprawy Wydziału Teologicznego USB po przeniesieniu do Białegostoku.

30 M. Paszkiewicz, Dziesięciolecie rządów arcybiskupa Romualda Jałbrzykowskiego w Białymstoku (1945-1955), WKAB, 6 (1980), nr 2, s. 96.

31 J. Pankiewicz, Dzieje, w: Archidiecezjalne Wyższe Seminarium Duchowne w Białymstoku 19451980, red. E. Ozorowski, s. 22.

32 M. Paszkiewicz, Kronika Seminarium Duchownego w Białymstoku 1945-1966, Białystok, mps, s. 16. 
wykłady, uczestniczył $\mathrm{w}$ radach profesorskich, egzaminował. W Seminarium w Białymstoku wykładał teologię pastoralną, dzieląc się swym bogatym kapłańskim doświadczeniem. Co roku przeprowadzał rozmowy z poszczególnymi klerykami, aby lepiej poznać kandydatów do kapłaństwa ${ }^{33}$. W trosce o zapewnienie bytu materialnego uczelni mianował księży prowizorów ${ }^{34}$. Rada Prowizorów obciążyła duchowieństwo parafialne miesięcznymi składkami. Wiejskie parafie zostały zobowiązane do dostarczania płodów rolnych ${ }^{35}$.

W dniach 4-6 września 1945 roku abp R. Jałbrzykowski wraz z ks. I. Świrskim przeprowadził pierwsze powojenne rekolekcje dla kapłanów w Białymstoku. Chciał swym słowem i przykładem umocnić ich na duchu i wskazać cele pracy duszpasterskiej ${ }^{36}$. Pragnął, aby duchowni starali się tworzyć wspólnoty kapłańskie.

Ksiądz I. Świrski był nie tylko rektorem Seminarium, ale także profesorem Wydziału Teologicznego USB w Białymstoku ${ }^{37}$. Mimo podjętych działań przez jego dziekana ks. Michała Klepacza i poparciu jego starań przez abp. R. Jałbrzykowskiego, władze państwowe nie chciały zalegalizować istnienia i działalności Wydziału Teologicznego, chociaż do początku 1947 roku pozwalały na wypłacanie pensji i deputatu na żywność. Podjęte próby legalizacji nie zostały uwieńczone sukcesem. Władze państwowe nie zatwierdzały stopni naukowych nadawanych przez Wydział i zamierzały połączyć go z Uniwersytetem Mikołaja Kopernika w Toruniu ${ }^{38}$. Ostatecznie zakazały jego działalności w 1948 roku, choć nieoficjalnie, profesorowie Wydziału Teologicznego USB prowadzili wykłady w ramach Seminarium Duchownego do 1951 roku $^{39}$.

Na Wydziale Teologicznym USB w Białymstoku, w pierwszym roku prowadzonych zajęć, miały miejsce dwa kolokwia habilitacyjne księży: ks. dr. Władysława Suszyńskiego (w 1946) za rozprawę pt. Idea Boga w filozoficznym rozwoju św. Augustyna i ks. dr. Walentego Urmanowicza (w 1946), za pracę pt. Źródła władzy państwowej. Studium moralne. Władze państwowe

33 T. Krahel, Jałbrzykowski Romuald 1945-1955, w: Archidiecezjalne Wyższe Seminarium Duchowne w Białymstoku 1945-1980, s. 67-69.

34 Byli nimi: ks. F. Pieściuk - prob. w Choroszczy, ks. A. Lewosz - prob. w Dojlidach i ks. A. Grabowski - prob. w Tryczówce.

35 AAB, Suszyński, Informacje o losach, s. 4; M. Paszkiewicz, Dziesięciolecie rządów, s. 96.

36 AAB, [S. Czyżewski], Ks. Dr Romuald Jałbrzykowski. Arcybiskup Metropolita Wileński. Wspomnienia, Białystok 1959, mps, s. 314.

37 Cz. Kłak, Siedleckie rekolekcje (ks. bp Ignacy Świrski - prof. Stanisław Pigoń), „Tematy i Konteksty" 2012, nr 2, s. 174-197.

38 S. Hołodok, Wydział Teologiczny Uniwersytetu Stefana Batorego w Białymstoku (1945-1951), „Studia Teologiczne”, 10(1992), s. 122-125.

39 AAB, Wydział Teologiczny USB w Białymstoku, Księga protokołów posiedzeń księży profesorów 1945-1955. 
nie uznały jednak tych habilitacji ${ }^{40}$. Tytuł magistra na Wydziale Teologicznym USB w Białymstoku otrzymało sześciu księży, w tym dwaj w 1946 roku: ks. Henryk Brzozowski na podstawie pracy Monografia parafii Dobrzyniewo $i$ ks. Edward Kisiel za pracę Czynnik moralny w genezie wiary według Mariana Zdziechowskiego.

Dnia 3 stycznia 1946 roku zmarł proboszcz i dziekan parafii farnej ks. A. Chodyko, dobroczyńca i współorganizator uczelni duchownej w Białymstoku.

Drugi rok akademicki trwał w białostockim Seminarium od 15 stycznia do 25 czerwca 1946 roku. Do 1 czerwca były wykłady, a następnie odbyła się sesja egzaminacyjna. Kolejny rok akademicki rozpoczął się już normalnie, po wakacyjnej przerwie, 21 września 1946 roku.

Dnia 5 września 1945 roku abp Jałbrzykowski gościł w Białymstoku kard. Augusta Hlonda, Prymasa Polski. Wizyta była swego rodzaju wyrazem wdzięczności i szacunku za lata cierpień i trudów poniesionych dla Kościoła i Ojczyzny w czasie wojny. Późniejsze nominacje profesorów Seminarium Duchownego w Białymstoku na biskupów świadczyły o tym, iż była to także wizyta mająca na celu zapoznanie się z kandydatami i zasięgnięcie o nich opinii ordynariusza.

30 marca 1946 roku został prekonizowany ordynariuszem biskupem siedleckim ks. prof. Ignacy Świrski, pierwszy rektor białostockiego Seminarium. 12 kwietnia 1946 roku otrzymał nominację na biskupa diecezji podlaskiej. 30 czerwca 1946 roku w prokatedrze odbyła się pierwsza w Białymstoku konsekracja biskupia, której przewodniczył kard. A. Hlond w asyście abp. Jałbrzykowskiego i bp. S. Łukomskiego z Łomży. Ceremoniarzem Kardynała był ks. Antoni Baraniak. 4 lipca 1946 roku odbył się ingres biskupa do katedry siedleckiej ${ }^{41}$.

30 czerwca, w dniu konsekracji bp. Świrskiego, święceń diakońskich w farze udzielił alumnom białostockiego Seminarium bp. Łukomski z Łomży.

W przeddzień konsekracji biskupiej, 29 czerwca 1946 roku, abp Jałbrzykowski udzielił święceń kapłańskich diakonom: Janowi Chmielewskiemu, Leonowi Piotrowskiemu i Mieczysławowi Stopczyńskiemu. Byli to ostatni absolwenci białostockiego Seminarium Duchownego, przy święceniach których uczestniczył rektor ks. I. Świrski ${ }^{42}$.

40 Rozprawy habilitacyjne odbyły się powtórnie na Uniwersytecie Warszawskiem 23-24 czerwca $1947 \mathrm{r}$.

41 J. Pankiewicz, I. Świrski 1945-1946, w: Archidiecezjalne Wyższe Seminarium Duchowne w Białymstoku 1945-1980, red. E. Ozorowski, s. 129-133.

42 M. Paszkiewicz, Kronika Seminarium Duchownego w Białymstoku 1945-1966, Białystok, mps, s. 16. 
Rektorem Seminarium Duchownego w Białymstoku, po odejściu ks. Świrskiego do Siedlec, został ks. Władysław Suszyński, dotychczasowy inspektor ${ }^{43}$.

\section{Bibliografia}

Archiwum Archidiecezjalne w Białymstoku, Kronika Archidiecezjalnego Seminarium Duchownego pod wezwaniem św. Jerzego Męcz. w Bialymstoku, t. I, Białystok 1959 , rkps.

Archiwum Archidiecezjalne w Białymstoku, Księga protokołów sesji księży profesorów Seminarium Duchownego, z lat 1944-1948, protokół z dn. 30 IV 1945 r.

Archiwum Archidiecezjalne w Białymstoku, Księga protokołów sesji księży profesorów Seminarium Duchownego, z lat 1944-1948, protokół z dn. 31 IV [błąd w zapisie, chodziło najprawdopodobniej o $1 \mathrm{~V}] 1945 \mathrm{r}$.

Archiwum Archidiecezjalne w Białymstoku, Kwit kasowy z 11 V 1945 r.

Archiwum Archidiecezjalne w Białymstoku, Pismo ks. A. Chodyki, dziekana białostockiego, do ks. prob. z Uhowa, z 10 X 1944 r.

Archiwum Archidiecezjalne w Białymstoku, Pismo ks. A. Chodyki, dziekana białostockiego, do ks. prob. z Uhowa, z 4 V 1945 r.

Archiwum Archidiecezjalne w Białymstoku, [S. Czyżewski], Ks. Dr Romuald Jałbrzykowski. Arcybiskup Metropolita Wileński. Wspomnienia, Białystok 1959, mps.

Archiwum Archidiecezjalne w Białymstoku, Seminarium Duchowne w Wilnie w czasie II wojny światowej, mps.

Archiwum Archidiecezjalne w Białymstoku, Sprawy lokalowe AWSD Orzeszkowa 5 i Słonimska 8, Pismo biskupa W. Suszyńskiego rektora AWSD do Kuratorium Okręgu Szkolnego Białostockiego, z dn. 4 IV 1960 r.

Archiwum Archidiecezjalne w Białymstoku, W. Suszyński, Informacje o losach Wileńskiego Seminarium Duchownego w czasie wojny od roku 1939 do dnia 5 sierpnia 1946, mps, s. 3.

Archiwum Archidiecezjalne w Białymstoku, Wydział Teologiczny USB w Białymstoku, Księga protokołów posiedzeń księży profesorów 1945-1955.

Archiwum Archidiecezjalne w Białymstoku, Zaproszenie na inaugurację roku akademickiego w Seminarium Duchownym w Białymstoku, z 21 V 1945 r.

Archiwum Państwowe w Białymstoku, sygn. I-137, k. 10, Pismo Kurii Arcybiskupiej w Białymstoku do Prezydium WRN w Białymstoku, z dn. 5 V 1972 r.

Biblioteka Litewskiej Akademii Nauk w Wilnie, F 31-19375, Lista święconych 17 marca 1945 r.;

Hołodok S., Wydział Teologiczny Uniwersytetu Stefana Batorego w Białymstoku (19451951), „Studia Teologiczne”, 10(1992).

43 Ibidem, s. 15-16. 
Krahel T., Jałbrzykowski Romuald 1945-1955, w: Archidiecezjalne Wyższe Seminarium Duchowne w Białymstoku 1945-1980, Białystok 1981.

Krahel T., Przez więzienia i obozy do kapłaństwa. Wojenne losy alumnów Seminarium Duchownego w Wilnie, Białystok 2015.

Kułak K., Wydział Teologiczny Uniwersytetu Stefana Batorego i Metropolitalne Seminarium Duchowne w Wilnie w czasie II wojny światowej, Lublin 1986, mps w BKUL.

Kłak Cz., Siedleckie rekolekcje (ks. bp Ignacy Świrski - prof. Stanisław Pigoń), „Tematy i Konteksty" 2012, nr 2.

Młynarski Z., Śp. Ksiądz Biskup Ignacy Świrski, „Gość Niedzielny” 38(1969), nr 17, s. 100.

Pamięci ks. Adolfa Trusewicza, „Magazyn Wileński” 2001, nr 5, s. 37.

Pankiewicz J., Dzieje, w: Archidiecezjalne Wyższe Seminarium Duchowne w Białymstoku 1945-1980, red. E. Ozorowski, Białystok 1981.

Pankiewicz J., Ignacy Świrski 1945-1946, w: Archidiecezjalne Wyższe Seminarium Duchowne w Białymstoku 1945-1980, red. E. Ozorowski, Białystok 1981.

Paszkiewicz M., Dziesięciolecie rządów arcybiskupa Romualda Jałbrzykowskiego w Biatymstoku (1945-1955), WKAB, 6 (1980), nr 2.

Paszkiewicz M., Kronika Seminarium Duchownego w Białymstoku 1945-1966, Białystok, mps.

Skorodiuk J., Cechy osobowe biskupa Ignacego Świrskiego, „Studia Włocławskie” 12(2009), s. 92-105.

Skorodiuk J., Historia życia biskupa I. Świrskiego, „Chrześcijanie”, t. 17, red. B. Bejze, Warszawa 1986.

Skreczko A., Ks. Ignacy Świrski - wychowawca i profesor (okres wileński i białostocki), w: Biskup Ignacy Świrski 1885-1968. Osoba i dzieło, red. B. Błoński, Siedlce 2008.

Szot A., Dom pachnacy chlebem. Słonimska 8. Dzieje Zgromadzenia Braci Sług Maryi Niepokalanej w Białymstoku, Białystok 2016.

Zawadzki J., Biskup Ignacy Świrski (1885-1968), „Collectanea Theologica” 38(1968), f. IV. 